\title{
Covid-19, Conflict, and Governance Evidence Summary No.28
}

\author{
Siân Herbert \\ GSDRC \& K4D, University of Birmingham \\ 15 January 2021
}

Welcome back to the fortnightly Covid-19, Conflict, and Governance Evidence Summary aims to signpost the UK Foreign, Commonwealth and Development Office (FCDO) and other UK government departments to the latest evidence and opinions on Covid-19 (C19), to inform and support their responses.

This summary features resources on: C19's unequal impacts and policy responses; responses to build long-term resilience to both conflict and pandemics; responses to support forcibly displaced people in Africa and the Middle East; and the implications of C19 for international development cooperation in 2021.

Many of the core C19 themes continue to be covered this week, including: C19 increasing gender-based violence; whether regime type shapes effective $\mathrm{C} 19$ responses; and whether and how $\mathrm{C} 19$ is shaping conflict contexts.

The summary uses two main sections - (1) literature: - this includes policy papers, academic articles, and long-form articles that go deeper than the typical blog; and (2) blogs \& news articles. See the end of this report for details on the method taken for this rapid summary. It is the result of one day of work, and is thus indicative but not comprehensive of all issues or publications. 


\section{LITERATURE}

\section{GOVERNANCE}

\begin{tabular}{|c|c|c|}
\hline Title/URL & $\begin{array}{l}\text { Name of } \\
\text { author; } \\
\text { publisher; } \\
\text { publication } \\
\text { type }\end{array}$ & Summary \\
\hline $\begin{array}{l}\text { COVID-19 and inequality: A } \\
\text { review of the evidence on } \\
\text { likely impact and policy } \\
\text { options }\end{array}$ & $\begin{array}{l}\text { Ruth Vargas } \\
\text { Hill \& Ambar } \\
\text { Narayan; } \\
\text { Centre for } \\
\text { Disaster } \\
\text { Protection; } \\
\text { Working } \\
\text { paper }\end{array}$ & $\begin{array}{l}\text { How is C19 impacting inequality? This paper } \\
\text { finds C19 is affecting disadvantaged } \\
\text { populations more, yet whether this translates } \\
\text { into higher inequality in a country depends } \\
\text { on the size, distribution, and duration of } \\
\text { C19-precipitated economic shocks, and on } \\
\text { C19 policy responses. } \\
\text { In the short term, the effect on income } \\
\text { inequality could go either way, depending on } \\
\text { how the impacts are distributed among the } \\
\text { poorest members of society (who are often } \\
\text { in rural areas and in agriculture in } \\
\text { developing countries, which tend to be less } \\
\text { affected) versus the less poor, and how } \\
\text { relief measures are able to temporarily } \\
\text { replace incomes. But over time, these } \\
\text { uneven impacts are likely to widen } \\
\text { opportunity gaps, leading to lower social } \\
\text { mobility and a more unequal distribution of } \\
\text { income and wealth, if adequate policy } \\
\text { measures are not adopted. A society with } \\
\text { larger pre-existing disparities will experience } \\
\text { more uneven impacts and recovery, with } \\
\text { worse implications for equality of } \\
\text { opportunities over time. As disadvantaged } \\
\text { groups suffer larger, longer-lasting shocks, } \\
\text { they are also more likely to adopt coping } \\
\text { mechanisms that: harm their future } \\
\text { economic prospects, reduce social mobility } \\
\text { across generations, and cause disparities in } \\
\text { inequality and wealth to persist and even } \\
\text { widen over time. Recent evidence from past } \\
\text { pandemics suggests fiscal policy has not } \\
\text { mitigated increases in inequality, highlighting } \\
\text { the need for a concerted policy effort. }\end{array}$ \\
\hline
\end{tabular}


Development Co-operation Report 2020
OECD;

Annual report
How did development cooperation trends change in 2020? This annual report finds that $\mathrm{C} 19$ has reversed progress on meeting the Sustainable Development Goals as over 100 million more people will enter into extreme poverty and 270 million people will go hungry in 2021. Some estimate that $\mathrm{C} 19$ will erode all human development gains made in the last decade. For many of the world's poorest and most vulnerable, C19 is not the primary threat to their lives and livelihoods, but it is exacerbating pre-existing inequalities which shape the distribution and severity of multidimensional impacts. While budget strains limit policy responses.

OECD countries account for $84 \%$ of total global funding raised to respond to $\mathrm{C} 19$, and developing countries still face a funding gap of at least USD1 trillion. All of the issues that development co-operation was grappling with pre-2020- increasing inequality and marginalised populations, women's economic empowerment and gender-based violence, precarious employment, humanitarian crises, and rising displacement- left populations and countries exposed when $\mathrm{C} 19$, though forecasted, bore down on an unprepared world.

C19 has tested development co-operation by disrupting working practices, partnerships and business models and putting unprecedented strain on public finances, yet donor agencies showed impressive agilitye.g. in reallocating budgeted funds and raising new resources. Initial estimates in this report suggest that Development Assistance Committee (DAC) members mobilised USD12 billion for $\mathrm{C} 19$. Yet the global economic downturn makes it uncertain whether ODA volumes can meet growing needs, and many 2020 appeals for funding missed their targets. Limited evidence and data sharing meant that decision-making faced extreme uncertainty. And while international co-ordination has been successful in some ways, e.g. in 


\begin{tabular}{|c|c|c|}
\hline & & $\begin{array}{l}\text { creating the Access to COVID-19 Tools } \\
\text { (ACT) Accelerator for the development, } \\
\text { production, and equitable access to C19 } \\
\text { tests, treatments, and vaccines, the } \\
\text { international community struggled to broker } \\
\text { co-ordinated responses and actions. } \\
\text { For resilience building, it recommends } \\
\text { international development actors: } \\
\text { - Integrate climate action in multi-sector } \\
\text { development strategies. } \\
\text { - Provide long-term support for country } \\
\text { systems. } \\
\text { - Avoid a development finance crisis. } \\
\text { International finance } \\
\text { - Step up collective action to provide and } \\
\text { protect global public goods. } \\
\text { - Develop strategies and contingencies for } \\
\text { international crisis co-ordination. }\end{array}$ \\
\hline $\begin{array}{l}\text { Health-system equity, } \\
\text { egalitarian democracy and } \\
\text { COVID-19 outcomes: An } \\
\text { empirical analysis }\end{array}$ & $\begin{array}{l}\text { Krishna } \\
\text { Chaitanya } \\
\text { Vadlamannati, } \\
\text { Arusha } \\
\text { Cooray \& } \\
\text { Indra de } \\
\text { Soysa; } \\
\text { Scandinavian } \\
\text { Journal of } \\
\text { Public Health; } \\
\text { Journal article }\end{array}$ & $\begin{array}{l}\text { Does the success of C19 responses vary } \\
\text { according to whether a country's form of } \\
\text { democracy is more 'egalitarian'? Using } \\
\text { econometric analysis, this paper finds that: } \\
\text { more equitable access to health care } \\
\text { increases testing rates and lowers C19 } \\
\text { death rates. However, broader egalitarian } \\
\text { governance, measured as egalitarian } \\
\text { democracy, shows the opposite effect. It } \\
\text { concludes that factors associated with } \\
\text { health-care capacity to reach and treat } \\
\text { matter more than broader societal factors } \\
\text { associated with social capital and trust. }\end{array}$ \\
\hline
\end{tabular}


Extra papers - without summary

\begin{tabular}{|l|l|}
\hline Title/URI & $\begin{array}{l}\text { Name of author; publisher; } \\
\text { publication type }\end{array}$ \\
\hline $\begin{array}{l}\text { How to Enhance Organisation Functioning in a } \\
\text { Pandemic: COVID-19 Lessons in Leadership }\end{array}$ & $\begin{array}{l}\text { Paul Englert; World Scientific } \\
\text { Publishing; Book chapter }\end{array}$ \\
\hline $\begin{array}{l}\text { Critical Speech in Southeast Asian Grey Literature } \\
\text { During the COVID-19 Pandemic }\end{array}$ & $\begin{array}{l}\text { Stewart Manley; Human Rights Law } \\
\text { Review; Journal article }\end{array}$ \\
\hline $\begin{array}{l}\text { The COVID-19 experience in the Fiji Islands: some } \\
\text { lessons for crisis management for small island } \\
\text { developing states of the Pacific region and beyond }\end{array}$ & $\begin{array}{l}\text { Rup Singh, Sumeet Lal, Mohsin } \\
\text { Khan, Arvind Patel, Ronal Chand \& } \\
\text { Devendra Kumar Jain; New } \\
\text { Zealand Economic Papers; Journal } \\
\text { article }\end{array}$ \\
\hline Role of Islamic Finance during COVID-19 & $\begin{array}{l}\text { Tanvir Alam; European Journal of } \\
\text { Islamic Finance; Journal article }\end{array}$ \\
\hline Race and Ethnicity in Pandemic Times & $\begin{array}{l}\text { China's Influence on Conflict Dynamics in South Asia } \\
\text { United States Institute of Peace } \\
\text { (USIP) Senior Study Group; USIP; } \\
\text { Report }\end{array}$ \\
\hline $\begin{array}{l}\text { Benjamin Opratko, Manuela } \\
\text { Bojadžijev, Sanja M. Bojanić, Irena } \\
\text { Fiket, Alexander Harder, Stefan } \\
\text { Jonsson, Mirjana Nećak, Anders } \\
\text { Neegard, Celina Ortega Soto, } \\
\text { \& Kristina Stojanović Čehajić; } \\
\text { Ethnic and Racial Studies; Journal } \\
\text { article }\end{array}$ \\
\hline
\end{tabular}




\section{CONFLICT}

\begin{tabular}{|c|c|c|}
\hline Title/URL & $\begin{array}{l}\text { Name of } \\
\text { author; } \\
\text { publisher; } \\
\text { publication } \\
\text { type }\end{array}$ & Summary \\
\hline $\begin{array}{l}\text { From crisis to opportunity for } \\
\text { sustainable peace: A joint } \\
\text { perspective on responding to } \\
\text { the health, employment and } \\
\text { peacebuilding challenges in } \\
\text { times of COVID-19 }\end{array}$ & $\begin{array}{l}\text { ILO, } \\
\text { Interpeace, } \\
\text { UN DPPA \& } \\
\text { WHO; Report }\end{array}$ & $\begin{array}{l}\text { How to harness the C19 crisis for positive } \\
\text { peace outcomes? This reports finds that C19 } \\
\text { and its responses can exacerbate } \\
\text { grievances, increase mistrust, discrimination } \\
\text { and perceptions of injustice over access to } \\
\text { health services, decent jobs and livelihoods } \\
\text { in countries affected by armed conflict or at } \\
\text { risk of violent outbreaks. Thus, C19 } \\
\text { responses should be part of long-term } \\
\text { recovery plans. It identifies responses that } \\
\text { can build resilience to both conflict and } \\
\text { pandemics including: scaling up existing } \\
\text { public employment programmes and social } \\
\text { protection schemes, and increasing } \\
\text { investment in productive infrastructure. E.g. } \\
\text { emergency public works schemes that } \\
\text { upgrade infrastructure for primary health } \\
\text { care and access to clean water, sanitation } \\
\text { and hygiene. While inclusive health and } \\
\text { socio-economic responses can give a voice } \\
\text { to local actors in decision-making and } \\
\text { encourage local responses, which could } \\
\text { contribute to increased trust in government } \\
\text { institutions and among groups. }\end{array}$ \\
\hline $\begin{array}{l}\text { COVID-19: Supporting } \\
\text { Forcibly Displaced People in } \\
\text { the Middle East and East } \\
\text { Africa }\end{array}$ & $\begin{array}{l}\text { Social } \\
\text { Science in } \\
\text { Humanitarian } \\
\text { Action; } \\
\text { Background } \\
\text { paper }\end{array}$ & $\begin{array}{l}\text { How to address the needs of displaced } \\
\text { people during C19? This report details the } \\
\text { disproportionate effects of C19 on forcibly } \\
\text { displaced populations, and examples of how } \\
\text { C19 responses are building on existing local } \\
\text { social and aid delivery structures particular } \\
\text { to the displacement context, including: using } \\
\text { displaced peoples' already existing } \\
\text { communication channels with politicians and } \\
\text { humanitarian agencies for C19 information; } \\
\text { leveraging the legitimacy of, and } \\
\text { relationships between, medical providers to } \\
\text { coordinate responses across fragmented } \\
\text { systems; and building on long-term }\end{array}$ \\
\hline
\end{tabular}




\begin{tabular}{|c|c|c|}
\hline & & $\begin{array}{l}\text { relationships between providers and patients } \\
\text { to maintain remote services for people with } \\
\text { chronic conditions. Refugee-led } \\
\text { organisations have also addressed gaps e.g. } \\
\text { in providing food. } \\
\text { To address the vulnerabilities of displaced } \\
\text { populations through localised C19 responses } \\
\text { the paper recommends: } \\
\text { - Promoting holistic public health responses } \\
\text { which address multiple C19 } \\
\text { vulnerabilities, avoid complete lockdowns, } \\
\text { protect peoples' existing homes and safe } \\
\text { spaces, and ensure border controls } \\
\text { balance the need to control transmission } \\
\text { with protecting asylum rights. } \\
\text { - Using research to tailor responses; } \\
\text { - Adopting a whole-of-society approach; } \\
\text { - Supporting organisations led by displaced } \\
\text { people; and } \\
\text { - Supporting local peace-making and } \\
\text { ceasefire efforts. }\end{array}$ \\
\hline $\begin{array}{l}\text { The Role of Local Government } \\
\text { in the Prevention of Violence } \\
\text { against Women and Girls } \\
\text { during the COVID-19 } \\
\text { Pandemic }\end{array}$ & $\begin{array}{l}\text { Valesca } \\
\text { Lima; Bulletin } \\
\text { of Latin } \\
\text { American } \\
\text { Research; } \\
\text { Journal } \\
\text { article }\end{array}$ & $\begin{array}{l}\text { How to address gender based violence } \\
\text { during C19? This article highlights the vital } \\
\text { role local governments play, with effective } \\
\text { responses including: investment in online } \\
\text { care services; temporary shelters for victims; } \\
\text { psychosocial support; and a strong } \\
\text { messages from law enforcement that } \\
\text { aggressors will be prosecuted. Besides } \\
\text { providing services, local and national } \\
\text { governments need to improve and facilitate } \\
\text { data collection. And women must be } \\
\text { involved in leading the C19 recovery. }\end{array}$ \\
\hline
\end{tabular}




\begin{tabular}{|l|l|}
\hline Title/URL & $\begin{array}{l}\text { Name of author; publisher; } \\
\text { publication type }\end{array}$ \\
\hline $\begin{array}{l}\text { COVID-19 and the Limitations of Official Responses to } \\
\text { Gender-Based Violence in Latin America: Evidence } \\
\text { from Ecuador }\end{array}$ & $\begin{array}{l}\text { Andrea Espinoza Carvajal; Bulletin } \\
\text { of Latin American Research; } \\
\text { Journal article }\end{array}$ \\
\hline $\begin{array}{l}\text { The COVID-19 Outbreak in North Africa: A Legal } \\
\text { Analysis }\end{array}$ & $\begin{array}{l}\text { Francesco Tamburini; } \\
\text { Journal of Asian and African } \\
\text { Studies; Journal article }\end{array}$ \\
\hline
\end{tabular}

\section{BLOGS \& NEWS ARTICLES}

\section{GOVERNANCE}

\begin{tabular}{|l|l|l|}
\hline Titie/URL & $\begin{array}{l}\text { Name of } \\
\text { author; } \\
\text { publisher; } \\
\text { pulolication } \\
\text { type }\end{array}$ & Summary \\
\hline $\begin{array}{l}\text { Africa: 'Repression \& } \\
\text { resistance are two key trends } \\
\text { heading into 2021' }\end{array}$ & $\begin{array}{l}\text { Nic } \\
\text { Cheeseman; } \\
\text { The Africa } \\
\text { Report; Blog }\end{array}$ & $\begin{array}{l}\text { What are key trends to watch for in Africa in } \\
\text { 2021? The blog highlights that the real } \\
\text { political story of 2020 is not the containment } \\
\text { of C19, but the way in which this set in } \\
\text { motion twin processes of repression and } \\
\text { resistance. These trends are likely to } \\
\text { intensify in 2021 as C19's economic impact } \\
\text { has hit Africa hard. As governments have } \\
\text { increased spending on healthcare, revenues } \\
\text { from tourism had fallen sharply, pushing an } \\
\text { increasing number of country's towards a } \\
\text { debt crisis. Zambia has already defaulted and } \\
\text { others are likely to follow. }\end{array}$ \\
\hline $\begin{array}{l}\text { Contrary to expectations, C19 did not } \\
\text { decimate Africa as it did Europe and North } \\
\text { America, due to early government } \\
\text { shutdowns, the rapid closure of borders, } \\
\text { younger populations, and warmer climates. }\end{array}$ \\
\hline
\end{tabular}




\begin{tabular}{|l|l|l|} 
& & $\begin{array}{l}\text { This is a significant success story, reminding } \\
\text { us that African states can act effectively and } \\
\text { decisively when it is in their interests to do } \\
\text { so. However, effective C19 responses came } \\
\text { at the cost of human rights and democracy, } \\
\text { further entrenching authoritarian regimes. }\end{array}$ \\
\hline $\begin{array}{l}\text { Calling for fair distribution of } \\
\text { Covid-19 vaccines to avoid } \\
\text { gender setback }\end{array}$ & $\begin{array}{l}\text { Plan } \\
\text { International; } \\
\text { Blog }\end{array}$ & $\begin{array}{l}\text { How could access to vaccines shape gender } \\
\text { inequality? The article highlights that unless } \\
\text { the vaccine is fairly distributed across the } \\
\text { world, women and girls' rights will be at risk, } \\
\text { due to them being disproportionately affected } \\
\text { by C19's impacts including gender-based } \\
\text { violence, being married against their will, } \\
\text { economic downturns, job losses and school } \\
\text { closures; Impacts that have already } \\
\text { worsened existing gender inequalities. }\end{array}$ \\
\hline
\end{tabular}

\section{Extra blogs \& news articles - without summary}

\begin{tabular}{|l|l|}
\hline Title/URL & $\begin{array}{l}\text { Name of author; publisher; } \\
\text { publication type }\end{array}$ \\
\hline Africa's Road to Recovery in 2021 is a Fresh Start & Alex Vines; Chatham House; Blog \\
\hline $\begin{array}{l}\text { COVID-19 impacts youth voices and hampers } \\
\text { participation }\end{array}$ & UNESCO; Blog \\
\hline $\begin{array}{l}\text { Corruption, Covid-19 and Inequality: the vital role of } \\
\text { companies in preventing this deadly mixture }\end{array}$ & Transparency International; Blog \\
\hline Analyzing Africa's Second Wave of COVID-19 & $\begin{array}{l}\text { Africa Center for Strategic Studies; } \\
\text { Blog }\end{array}$ \\
\hline
\end{tabular}




\section{CONFLICT}

\begin{tabular}{|c|c|c|}
\hline Title/URL & $\begin{array}{l}\text { Name of } \\
\text { author; } \\
\text { publisher; } \\
\text { publication } \\
\text { type }\end{array}$ & Summary \\
\hline 10 Conflicts to Watch in 2021 & $\begin{array}{l}\text { Robert } \\
\text { Malley; ICG; } \\
\text { Commentary }\end{array}$ & $\begin{array}{l}\text { What conflicts are at risk of worsening during } \\
2021 \text { and why? This blog highlights that if } \\
\text { there were a contest for the } 2020 \text { event with } \\
\text { the most far-reaching implications for global } \\
\text { peace and security, the field would be } \\
\text { crowded. In regards to C19 it recognises that } \\
\text { when C19 first broke out, many feared it } \\
\text { would have immediate, potentially } \\
\text { devastating consequence in developing } \\
\text { countries facing deadly conflict. Although } \\
\text { several low-income countries were hit badly, } \\
\text { many were not; diplomatic activity, } \\
\text { international mediation, peacekeeping } \\
\text { missions, and financial support to vulnerable } \\
\text { populations suffered, but it's questionable } \\
\text { whether C19 dramatically affected the } \\
\text { trajectory of major wars, be they in } \\
\text { Afghanistan, Libya, Syria, Yemen, or } \\
\text { elsewhere. } \\
\text { Yet the longer-term ramifications are a } \\
\text { different matter, with a global economic crisis } \\
\text { without precedent since World War II, and an } \\
\text { additional } 150 \text { million people being driven } \\
\text { below the extreme poverty line. Although } \\
\text { income levels do not directly correlate with } \\
\text { conflict, violence is more likely during periods } \\
\text { of economic volatility. }\end{array}$ \\
\hline
\end{tabular}




\section{VIDEOS \& PODCASTS}

\begin{tabular}{|l|l|l|}
\hline Title/URL & $\begin{array}{l}\text { Name of } \\
\text { author; } \\
\text { publisher; } \\
\text { publication } \\
\text { type }\end{array}$ & Summary \\
\hline $\begin{array}{l}\text { Conflict, Climate, and } \\
\text { Covid-19 }\end{array}$ & $\begin{array}{l}\text { Centre for } \\
\text { Strategic } \\
\text { and } \\
\text { International } \\
\text { Studies } \\
\text { (CSIS) }\end{array}$ & $\begin{array}{l}\text { In this audio, the CSIS hosts a discussion on the } \\
\text { International Rescue Committee's newly released } \\
\text { 2021 Emergency Watchlist, and how nearly every } \\
\text { watchlist country is facing the triple-threat of } \\
\text { ongoing conflict, climate change, and the Covid-19 } \\
\text { pandemic. }\end{array}$ \\
\hline
\end{tabular}

\section{EVENTS}

25 January - 14:00-15:30, COVID-19 and its Impact on Gender, Justice and Security, LSE. This event explores: How have responses to $\mathrm{C} 19$ affected the fight for gender justice and inclusive security? What are the impacts of the crisis on political and social rights agendas? Has C19 exacerbated the closing down of civil society space? How are gender roles and conceptions of masculinity challenged as a result of the reconfiguration of public and private spaces? And, perhaps most importantly, as we head towards a post-C19 reckoning: does the moment of crisis brought about by the pandemic offer opportunities for positive change?

26 January - 13:15-14:15, Coronavirus and the Politics of Science, University of Birmingham. This event explores C19 responses in a number of case studies (Brazil, Britain, China, Germany, Italy, Russia, USA), by comparing responses, it explores the differences in the politics of information, communication, and public policies seeking to balance health and economic objectives. 


\section{DASHBOARDS, TRACKERS \& RESOURCE HUBS}

K4D - Covid-19 Resource Hub

Global Voices - Covid-19: Global voices for a pandemic

ICNL - COVID-19 Civic Freedom Tracker

ECPR Standing Group on Organised Crime - Controcorrente (dedicated Covid-19 blog series)

The Syllabus - The politics of Covid-19 readings

Political Settlements Research Programme - Conflict, development and Covid-19 resources

IDS - Covid-19: the social science response to the pandemic

GI-TOC - Covid Crime Watch

CGD - Coronavirus preparedness \& response

ODI - Reforms, initiatives and campaigns on migrants' contributions to the Covid-19 response

OECD - Tackling coronavirus (COVID-19) Contributing to a global effort resource hub

The New Humanitarian - Coronavirus news, data, and policy response tracker

ACLED - Covid-19 disorder tracker

Various - Crowd-sourced cross-disciplinary coronavirus syllabus

African Arguments - Coronavirus in Africa Tracker

Insecurity insight - Covid-19 and security monitoring

Council on Foreign Relations - Peace, Conflict, and Covid-19

KPMG - Covid-19 tax developments

European Council on Foreign Relations - European solidarity tracker

Westminster Foundation for Democracy - Pandemic Democracy Tracker

ACAPS - Covid-19 ACAPS Resources

ReliefWeb - Covid-19 Global Hub

The Economist - Covid-19 news

IPA - RECOVR Research Hub

Dalia research - Democracy Perception Index 2020

V-Dem Institute - Pandemic Democratic Violations Index

Gender and Covid-19 - Gender and Covid-19 
University of Oxford - Coronavirus Government Response Tracker

UNDP - COVID-19 Global Gender Response Tracker

K4D - COVID-19 Evidence Search

ACAPS - Secondary impacts of C19

OECD States of Fragility - Covid-19, Crises, and Fragility

International IDEA - Global Monitor of COVID-19's impact on Democracy and Human Rights

International IDEA - Global overview of COVID-19: Impact on elections

COVID-DEM - COVID-19 and democratic governance information hub

COVID-19 Humanitarian - COVID-19 and Humanitarian Crises

COVID-19 High-Frequency Monitoring Dashboard - World Bank

\section{Suggested citation}

Herbert, S. (2021). COVID-19 Conflict and Governance Evidence Summary No.28. K4D

Evidence Summary. Brighton, UK: Institute of Development Studies. DOI:

10.19088/K4D.2021.008

\section{Methodology}

Due to the emerging nature of the Covid-19 crisis, this rapid weekly summary includes blogs, and news articles, in addition to policy and academic literature. The sources included are found through searches of Google and ReliefWeb with the keywords:

(“COVID-19" OR "coronavirus") AND ("developing countries" OR "Africa" OR "Asia" OR "Middle East" OR "Latin America" OR "Pacific") AND ("conflict" OR "peace" OR "violence" OR "resilience" OR

"fragility")

("COVID-19" OR "coronavirus") AND ("authoritarian*” OR "democracy" OR "corrupt" OR "transparency" OR "state legitimacy" OR "non-state actors" OR "state capacity" OR "state authority" OR "politic*" OR "state institutions")

Plus searches of Google Scholar with the keywords:

("COVID-19" OR "coronavirus") AND ("developing countries" OR "Africa" OR "Asia" OR "Middle East" OR "Latin America" OR "Pacific")

("COVID-19" OR "coronavirus") AND ("developing countries" OR "Africa" OR "Asia" OR "Middle East" OR "Latin America" OR "Pacific") AND ("conflict" OR "peace" OR "violence" OR "resilience" OR "fragility")

("COVID-19" OR "coronavirus") AND ("authoritarian*" OR "democracy" OR "corruption" OR "transparency" OR "state legitimacy" OR "non-state actors" OR "state capacity" OR "state authority" OR "politic*" OR "state institutions") 
The searches are restricted to articles published in the previous seven days, in English. This is complemented by: a focussed Twitter search (using just the pages of a small selection of research organisations, and key scholars/thinkers, including those funded by the UK government's FCDO; and through email recommendations from FCDO advisors and leading experts. This is trial and error approach, which will be refined and changed over the coming weeks. If you have literature to include in the weekly summary, please email - s.herbert@bham.ac.uk

Thanks to Professor Heather Marquette for expert advice.

\section{About this report}

This two-weekly COVID-19 conflict and governance evidence summary is based on 1 day of desk-based research. $K 4 D$ services are provided by a consortium of leading organisations working in international development, led by the Institute of Development Studies (IDS), with Education Development Trust, Itad, University of Leeds Nuffield Centre for International Health and Development, Liverpool School of Tropical Medicine (LSTM), University of Birmingham International Development Department (IDD) and the University of Manchester Humanitarian and Conflict Response Institute (HCRI).

This evidence summary was prepared for the UK Government's Foreign, Commonwealth and Development Office (FCDO) and its partners in support of pro-poor programmes. Except where otherwise stated, it is licensed for non-commercial purposes under the terms of the Open Government Licence v3.0. K4D cannot be held responsible for errors, omissions or any consequences arising from the use of information contained in this conflict and governance evidence summary. Any views and opinions expressed do not necessarily reflect from the British people those of FCDO, K4D or any other contributing organisation.

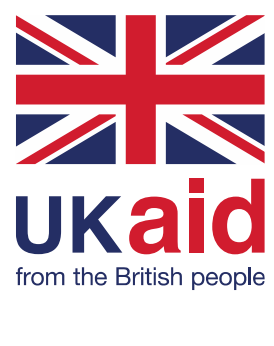

(C) Crown copyright 2021. 